University of Wollongong

Research Online

Faculty of Law, Humanities and the Arts Papers (Archive)

Faculty of Arts, Social Sciences \& Humanities

$1-1-2017$

Asian Servants for the Imperial Telegraph: Imagining North Australia as an Indian Ocean Colony before 1914

Julia T. Martinez

University of Wollongong, juliam@uow.edu.au

Follow this and additional works at: https://ro.uow.edu.au/lhapapers

Part of the Arts and Humanities Commons, and the Law Commons

Research Online is the open access institutional repository for the University of Wollongong. For further information contact the UOW Library: research-pubs@uow.edu.au 


\title{
Asian Servants for the Imperial Telegraph: Imagining North Australia as an Indian Ocean Colony before 1914
}

\author{
Abstract \\ In the late nineteenth century, the officers of the Eastern Extension Australasia and China Telegraph \\ Company provided north Australia with a cable connection to London via Java, Singapore, and India. The \\ telegraph project prompted a new era of colonisation in tropical north Australia and the officers of the \\ company sought to ensure that the north would be shaped according to their notions of Indian Ocean \\ colonial culture. They insisted on employing Asian domestic servants in opposition to White Australian \\ nationalists who advocated restrictions on Asian migration. Like the pearling industry, which was \\ permitted ongoing access to Asian labour, the telegraph company drew on the support of liberal \\ parliamentarians, and leveraged their privileged position as providers of imperial telecommunications to \\ develop an elite colonial counter-culture in north Australia.

\section{Disciplines} \\ Arts and Humanities | Law

\section{Publication Details} \\ Martinez, J. (2017). Asian Servants for the Imperial Telegraph: Imagining North Australia as an Indian \\ Ocean Colony before 1914. Australian Historical Studies, 48 (2), 227-243.
}


Asian Servants for the Imperial Telegraph: Imagining North Australia as an Indian

Ocean Colony before 1914

\section{JULIA MARTÍNEZ}

In the late nineteenth century, the officers of the Eastern Extension Australasia and

China Telegraph Company provided north Australia with a cable connection to London via Java, Singapore, and India. The telegraph project prompted a new era of colonisation in tropical north Australia and the officers of the company sought to ensure that the north would be shaped according to their notions of Indian Ocean colonial culture. They insisted on employing Asian domestic servants in opposition to White Australian nationalists who advocated restrictions on Asian migration. Like the pearling industry, which was permitted on-going access to Asian labour, the telegraph company drew on the support of liberal parliamentarians, and leveraged their privileged position as providers of imperial telecommunications to develop an elite colonial counterculture in north Australia.

In 1907 William Warren, Manager of the Eastern Extension Australasia and China Telegraph Company, sought permission to import two domestic servants into Western Australia. ${ }^{1} \mathrm{He}$ was relaying a request from Josiah Fenton, Superintendent of the Roebuck Bay Cable Station who had noted: 'Madras boys for preference, or in the event of being unable to obtain suitable ones from there, then Malays or Chinese from Singapore'.2 British-born Warren was not concerned that the entry of Asian workers might be construed as a breach of the White Australia policy. Forty years earlier, he

My thanks to Heather Goodall and Devleena Ghosh for suggesting the Indian Ocean focus. Thanks also to Frances Steel, Claire Lowrie, Sharon Crozier-De Rosa, Cecilia Leong-Salobir, and Ben Maddison for commenting on draft versions. I acknowledge funding from the Australian Research Council, DP110100490.

${ }^{1}$ The amalgamated Eastern Extension Australasia and China Telegraph Company Limited (known as the Eastern Extension) was formed in 1873.

${ }^{2}$ Warren, Manager in Australasia, Melbourne, 17 December 1907, to Sec. Department of External Affairs, 'Eastern Extension Australasia and China Telegraph Coy', A1 1913/12793, Barcode 16092, National Archives of Australia (hereafter NAA). 
had helped install the telegraph cable from Suez to Bombay and had travelled to Australia along with the newly established cable. As a British imperialist, shaped by his experience of Indian Ocean colonies, this racialised framing of Asian workers as suitable 'house boys' would have been commonplace. ${ }^{3}$ As for Josiah Fenton, who had arrived at the Cable Station in Broome (Roebuck Bay) in 1903, his request for servants reflected his own background as an Anglo-Indian, born in Madras, and educated in England. ${ }^{4}$

Thomas Metcalf, in writing about India in Imperial Connections, has advocated a shift away from the more traditional historiographical emphasis on colonial ties to the metropole. He regards the telegraph as the embodiment of those traditional 'vertical' connections 'through which information flows up and policy directives flow down — running from each colony to the metropole in London'. ${ }^{5}$ The telegraph, like other tools of empire, such as the steamship and the railroad, was understood as aiding in the consolidation of the British imperial project. ${ }^{6}$ In 1867 ,

\footnotetext{
3 'Obituary Mr. William Warren’, Daily Telegraph, (Launceston), 5 July 1918, 4.

${ }^{4}$ The term Anglo-Indian refers to white Britons resident or born in India. 'Funeral, The Late Mr. J C Fenton', West Australian, 16 April 1934, 13.

${ }^{5}$ Thomas R. Metcalf, Imperial Connections: India in the Indian Ocean Arena, 1860-1920 (Berkeley: University of California Press, 2007), 6; See also Donald Read, The Power of New, the History of Reuters (Oxford: Oxford University Press, 1999), 21; Tony Ballantyne and Antoinette Burton, 'Empires and the Reach of the Global', in A World Connecting 1870-1945, ed. Emily S. Rosenberg (Cambridge, MA: Harvard University Press, 2012), 358; C. A. Bayly, The Birth of the Modern World 1780-1914, Global Connections and Comparisons (Malden, M.A.: Blackwell Publishing 2004).

${ }^{6}$ Ben Marsden and Crosbie Smith, Engineering Empires, A Cultural History of Technology in Nineteenth-Century Britain (Houndmills: Palgrave Macmillan, 2005), 11; Daniel Headrick, The Tools of Empire, Technology and European Imperialism in the Nineteenth Century (New York: Oxford University Press, 1981), 158.
} 
Singapore, Penang and Malacca, which had previously been governed from British India, came under the control of the Colonial Office in London and the telegraph was intended to facilitate communication between London and the Indian Ocean colonies. But an alternative reading of telegraph history, might show how the undersea cables also served as 'horizontal' connections between the Indian Ocean colonies; as examples of Tony Ballantyne's 'webs of empire', a spatial framing which imagines inter-colonial ties between India and New Zealand. ${ }^{7}$ My aim here is to explore the cultural and political ramifications of north Australia's telegraph connection to the Indian Ocean colonies. I am not so much concerned with the disembodied telegraphic messages, as with the people employed by the telegraph company in its northern stations in Darwin and Broome. Tracing their 'connective cultural traffic', unsettles Australian national narratives by foregrounding commonalities with other Indian Ocean colonies and brings into focus the interconnected Indian Ocean world. ${ }^{8}$ In particular I consider the mobility of telegraph officers like Fenton, and the Asian domestic servants they employed.

The telegraph officers who were stationed in northern Australia were, over the course of their 'imperial careers', highly mobile across the empire. ${ }^{9}$ W. G. Baker was appointed to the Darwin cable station in 1878 . When he retired in 1935 , he was manager of the Eastern Extension in Singapore. He had in the meantime worked in

\footnotetext{
${ }^{7}$ Tony Ballantyne, 'Race and the webs of empire: Aryanism from India to the Pacific', Journal of Colonialism and Colonial History 2, no. 3 (2001).

${ }^{8}$ Tony Ballantyne, 'Mobility, empire, colonisation', History Australia 11, no. 2 (August 2014): 37.

${ }^{9}$ David Lambert and Alan Lester, 'Introduction: Imperial spaces, imperial subjects' in Colonial Lives Across the British Empire: Imperial Careering in the Long Nineteenth Century (Cambridge:

Cambridge University Press 2006), 2.
} 
Canada, New Zealand, Madras, Hong Kong, and Shanghai. ${ }^{10}$ R.W. Bernard, from County Wicklow, Ireland, started with the company in Madras in 1873, and moved to become superintendent at Penang and Singapore, before moving to Darwin around 1883. ${ }^{11}$ New Zealander Ogle Moore moved to Darwin for twelve months in 1894, before working in Banyuwangi in Java. Moore hints at the racialised hierarchy of company employees, writing to his mother that he was glad to live apart from the ten Madras staff at Banyuwangi station, a social distance he explained by citing their 'very small salaries' and their diet of 'curry and rice'. ${ }^{12}$

From its inception, the telegraph project was largely responsible for the colonisation of Port Darwin and for the consolidation of north Australia as a new imperial space. ${ }^{13}$ The Eastern Extension telegraph officers became known as advocates of a racialised colonial model, in which Australia's north was imagined as an Indian Ocean colony. As Warren's request demonstrates, this model stood in opposition to the restrictive immigration policy of White Australia after 1901. The Eastern Extension labour migration lobby was part of a broader imperial project promoting Asian labour in the north. As Claire Lowrie shows in relation to Chinese servants in Darwin, it was the elite - or as novelist Xavier Herbert suggests, the would-be elite - who looked to develop and sustain these colonial cultural models. ${ }^{14}$

\footnotetext{
${ }^{10}$ South Australian Register, 12 July 1878, 15; Straits Times, 15 February 1935, 12.

${ }^{11}$ Straits Times, 30 March 1901, 2; Advertiser 18 July 1890, 4.

12 ‘At Banjoewangi, A Graphic Description', Wairarapa Daily Times, 6 March 1896, 3.

${ }^{13}$ Officially Palmerston before 1911, but often referred to by the harbour name Port Darwin.

${ }^{14}$ Claire K. Lowrie, 'White "men” and their Chinese "boys": Sexuality, masculinity and colonial power in Singapore and Darwin, 1880s to 1930s', History Australia 10, no. 1 (April 2013): 35-57; Xavier Herbert, Capricornia (Sydney: Pacific Book, 1937), 32; Julia Martínez, 'Plural Australia: Aboriginal and Asian Labour in Tropical White Australia, Darwin, 1911-1940’ (PhD thesis, University of
} 
What grew out of these imperial designs, was a legacy of Asian immigration and Asian-Indigenous encounters that are now celebrated as important counter-cultural challenges to the hegemonic national histories of White Australia. ${ }^{15}$ The pearling industry in particular, well-known for having been granted an exemption to employ Asian labour, facilitated the entry of thousands of Asian workers. ${ }^{16}$ Here, I explore a different, almost unknown case of exemption that was granted to the Eastern Extension. It was a relatively short-lived reprieve from the White Australia policy, but one which nevertheless serves to complicate our understanding of the politics of Asian immigration to Australia.

\section{Early telegraph history between Australia and Asia}

In 1871 the British Australian Telegraph Company (BAT) - the precursor to the amalgamated Eastern Extension - made the final link that connected Australia to

Wollongong, 2000), 175. See also Claire K. Lowrie, Masters and Servants, Cultures of Empire in the Tropics (Manchester: Manchester University Press, 2016).

${ }^{15}$ See Henry Reynolds, North of Capricorn, The Untold Story of Australia's North (Sydney: Allen \& Unwin, 2003); Regina Ganter, with contributions from Julia Martinez and Gary Lee, Mixed Relations: Asian-Aboriginal Contact in North Australia (Perth: University of Western Australian Press, 2006); Peta Stephenson, The Outsiders Within, Telling Australia's Indigenous-Asian Story (Sydney: UNSW Press, 2007); Anna Shnukal and Guy Ramsay, 'Tidal flows: an overview of Torres Strait IslanderAsian contact', in Navigating boundaries: the Asian diaspora in Torres Strait, eds Anna Shnukal, Guy Ramsay and Yuriko Nagata (Canberra: Pandanus Books 2004); Samia Khatun, 'Camels, Ships and Trains: Translation Across the "Indian Archipelago", 1860-1930' (PhD thesis, University of Sydney, 2012).

${ }^{16}$ Julia Martínez and Adrian Vickers, The Pearl Frontier, Indonesian Labor and Indigenous Encounters in Australia's Northern Trading Network (Honolulu: University of Hawai'i Press, 2015) 
London, laying an undersea cable between the purpose-built colony of Port Darwin to Banyuwangi in Java. From Java it joined the existing cable that passed through Batavia (Jakarta), Singapore, Penang, and Madras. A second cable connected Broome on the north coast of Western Australia to Java in 1889.

Compared with the rich literature on British-Indian telegraph history we know almost nothing of telegraph history between the Dutch East Indies and north Australia. ${ }^{17}$ The Dutch East Indies link was an anomaly within this otherwise allBritish telegraph line. In his history of global telegraphy, Roland Wenzlhuemer notes only that Port Darwin was 'brought into telegraphic communication with Java, and therefore with the world'. ${ }^{18}$ Java was imagined as an intermediary link, passing messages between Australia and London. Even so, as historian Paul Battersby acknowledges, the Darwin-Java telegraph connection promoted trade with the Dutch East Indies, and gave Australia 'a vested interest' in security in the Archipelago. ${ }^{19}$

If the Australia-Java connection has been overlooked by historians, it is because the cable straddled the geographic boundaries of Southeast Asia and

\footnotetext{
${ }^{17}$ D.K. Lahiri Choudhury, Telegraphic Imperialism: Crisis and Panic in the Indian Empire, c. 1830, (Basingstoke: Palgrave Macmillan, 2010); Amelia Bonea, 'Telegraphy and Journalism in Colonial India, c. 1830s-1900', History Compass 12, no. 5 (2014): 387-97; Wim Ravesteijnand Marie-Louise ten Horn-van Nispen, 'Engineering an Empire: The Creation of Infrastructural Systems in the Netherlands East Indies, 1800-1950', Indonesia and the Malay World 35, no. 10 (2007): 273-92.

${ }^{18}$ Roland Wenzlhuemer, Connecting the Nineteenth-Century World: The Telegraph and Globalization, (Cambridge: Cambridge University Press, 2012), 113.

${ }^{19}$ Paul Battersby, To the Islands: White Australians and the Malay Archipelago since 1788 (Plymouth: Lexington Books, 2007), 25.
} 
Australia. ${ }^{20}$ More recently, Willem van Schendel commended the study of borderlands as a way of rethinking Southeast Asian area studies. ${ }^{21}$ In Australia, scholars have similarly questioned Australia's isolationist history; Ruth Balint suggests that we embrace the idea of the Timor and Arafura seas as a contact zone, as 'a place of exchange'.22 Prior to the establishment of the Darwin-Java telegraph link there were pre-colonial connections between north Australia and present-day Indonesia in the form of Macassan and Bugis fishing fleets coming to north Australia in search of the lucrative maritime product trepang. ${ }^{23}$ The advent of the pearl-shell industry in the 1860s led to the introduction of indentured workers from the Dutch East Indies, Singapore, Japan and the Philippines. ${ }^{24}$ In later years the pearling masters in Broome and Darwin would work closely with telegraph officers in their lobby to import Asian workers.

George Windsor Earl, previously Commissioner of Crown lands at Port Essington in north Australia, first put the idea of using the telegraph line to connect

\footnotetext{
${ }^{20}$ Robert Cribb mentioned the Java-Australia telegraph line in an unpublished essay on Queensland's bid to be the landing site for the cable, 'The Mystery of the Lost Cable, Queensland and Australia's overseas telegraph link, 1854-1875', unpublished paper, 1979.

${ }^{21}$ Willem van Schendel, 'Southeast Asia, An idea whose time is past?', Bijdragen tot de Taal-, Landen Volkenkunde 168, no. 4 (2012): 500.

${ }^{22}$ Ruth Balint, 'Epilogue: the yellow sea', in Australia's Asia: From yellow peril to Asian century, eds David Walker and Agnieszka Sobocinska (Perth: UWA Publishing, 2012), 347.

${ }^{23}$ C.C. Macknight, The Voyage to Marege': Macassan Trepangers in Northern Australia (Melbourne: Melbourne University Press, 1976).

${ }^{24}$ Martínez and Vickers.
} 
Australia to India to the New South Wales Legislative Council in $1855 .{ }^{25} \mathrm{He}$ proposed that a steamship carry Australian mail to the soon-to-be-completed telegraph station at Banyuwangi in Java. He did not envisage the cable reaching Australia because the deep strait separating Java from Bali was believed to be 'unfathomable'. Instead the Australasian Steam Navigation Company offered to put steamships onto that route for a subsidy of $£ 96,000 .{ }^{26}$ During this period the "mailed telegram' relied on a combination of cable and ship. ${ }^{27}$ In the same year Charles Todd from the Royal Observatory began as South Australian superintendent of the overland telegraph. $^{28}$

A telegraph cable connection between Australia and India was discussed in 1857 with the proposed route going via Ceylon, Sumatra, Java, Sandalwood (Sumba) Island, and from there to north Australia sites of Melville Island (Tiwi Islands) and Raffles Bay - both abandoned British settlements from the 1820s. ${ }^{29}$ The Dutch undertook to lay a cable between Batavia and Singapore in 1859 and gave permission to Frederick Gisborne to erect a station at Kupang in Dutch Timor, but this part of the

\footnotetext{
${ }^{25}$ George Windsor Earl, The Eastern Seas, Voyages and Adventures in the Indian Archipelago, in 1832-33-34, Comprising a Tour of the Island of Java-Visits to Borneo, the Malay Peninsula, Siam (London: W.H. Allen, 1837), 433.

${ }^{26}$ Moreton Bay Courier, 22 September 1855, 2.

${ }^{27}$ Peter Putnis, 'News, Time and Imagined Community in Colonial Australia', Media History 16, no. 2 (2010): 161 .

${ }^{28}$ Jack Cross, Great Central State: The Foundation of the Northern Territory (Adelaide: Wakefield Press, 2011), 5.

${ }^{29}$ Argus, 24 November $1857,6$.
} 
plan was never realised. ${ }^{30}$ The need for a secure landing site for the cable encouraged the Dutch to seek greater administrative control over the eastern archipelago. ${ }^{31}$ Van Delden, a representative of Dutch East Indies shipping companies, commented that while the telegraph line to Banyuwangi existed, 'the islands easterly of Java are not all under regular government, and great difficulties are in the way of extending the line in that direction'. ${ }^{32}$ Eventually the telegraph route limited Dutch involvement by going direct from Banyuwangi to Darwin.

In 1862, the Colonial Office recommended dividing the Northern Territory along the tropic of Capricorn, with the southern part allocated to South Australia and the north to Queensland, which would then control the cable line. ${ }^{33}$ Queensland's government, however, declined to assume responsibility for the Northern Territory. Instead South Australia agreed to annex the Northern Territory after explorer John McDouall Stuart demonstrated that it was possible to establish an overland telegraph line from Adelaide in the south to the north coast. ${ }^{34}$ The landing site of Port Darwin was eventually chosen and George Woodroffe Goyder, the Surveyor General, laid out

\footnotetext{
${ }^{30}$ Sydney Morning Herald, 5 December 1859, 5; Dwayne, R. Winseck, and M. Robert Pike, Communication and Empire: Media, Markets and Globalization, 1860-1930 (Durham NC: Duke
} University Press, 2007), 39.

${ }^{31}$ H.L. Wesseling, The European Colonial Empires, 1815-1919, Diane Webb (Trans.), (Harlow: Pearson Longman, 2004), 206; Stephan Dietrich, 'Flores in the nineteenth century: Aspects of Dutch colonialism in a non-profitable island', Indonesia Circle 11, no. 31 (1983): 39.

${ }^{32}$ Queenslander, 14 July 1866, 8.

${ }^{33}$ Alan Powell, Far Country: A Short History of the Northern Territory (Melbourne: Melbourne University Press, 1982), 73-4; Cribb.

${ }^{34}$ Earl James, 'The Ill-Fated Escape Cliffs (Northern Territory) Survey Expedition, 1864-66', The Globe: Journal of the Australian Map Circle Inc, 63 (2009): 5; South Australian Census, 1860. http://hccda.ada.edu.au/pages/SA-1860-census-02_1 (accessed 3 March 2014). 
the town in preparation. He informed the South Australian authorities that the land belonged to the Larrakia (Larrakeeyah) people, and the neighbouring Djerimanga (Woolner), and Kingarakan (Warnunger) who regarded this as 'unauthorised and unwarranted occupation of their country'.35 As with other colonial projects the prospect of resistance by the traditional owners did not deter them from going ahead. ${ }^{36}$ Goyder also argued that the new colony would be unlikely to sustain a large white settlement, with the oppressive heat 'as bad as some parts of India'. He anticipated that the colony would require Asian labour from Java or Singapore. ${ }^{37}$

With the new settlement being largely established to serve the needs of the cable company, it is not surprising that there developed a close relationship between the administration and private enterprise. Captain William Bloomfield Douglas was appointed Government Resident in March 1870. He had what was deemed appropriate maritime experience in Asia, including fighting 'pirates' alongside Sir James Brooke, the 'white rajah' of Sarawak. ${ }^{38}$ Soon after, in September 1871 the staff

\footnotetext{
${ }^{35}$ Powell, Far Country, 83.

${ }^{36}$ See Samantha Wells, 'Negotiating Place in Colonial Darwin, Interactions between Aborigines and whites, 1869-1911' (PhD thesis, University of Technology, Sydney, 2003).

${ }^{37}$ Douglas Lockwood, The Front Door, Darwin, 1869-1969 (London: Angus \& Robertson, 1969), 317; David Johanson, 'History of the White Australia Policy', in Immigration: Control or Colour Bar? The Background to 'White Australia' and a Proposal for Change, ed. Kenneth Rivett (Melbourne: Melbourne University Press, 1962), 21.

${ }^{38}$ P. L. Burns, 'Douglas, William Bloomfield (1822-1906)', Australian Dictionary of Biography, National Centre of Biography, Australian National University, http://adb.anu.edu.au/biography/douglas-william-bloomfield-3431/text5223, published first in hardcopy 1972, (accessed 20 October 2015).
} 
of the BAT arrived on the Bengal into Port Darwin. ${ }^{39}$ The undersea cable came from London on the 6 November on the S.S. Edinburgh. Second Officer James Nicol, recalled arriving in Darwin's 'splendid safe harbor', and being struck by the newness of the colony with 'scarcely a handful of white settlers' ${ }^{40}$

With the cable installed in Darwin, the Edinburgh returned to Java, laying cable as it went. On 19 November 1871, in Banyuwangi, the BAT completed the cable connection allowing the telegraphic communication between Australia and Britain. Nicol wrote: 'We had messages of congratulation from England and from Australia when we arrived that night, all working satisfactory'. ${ }^{41}$ Captain Robert Charles Halpin, commander of the cable fleet, sent a celebratory message back to Captain Douglas in Darwin. ${ }^{42}$ The cable fleet remained in Banyuwangi for the next month, repairing equipment and indulging in hunting parties on the island of Bali until the Darwin authorities used the new telegraph to request that the Edinburgh return to Darwin with provisions from Java. ${ }^{43}$ In this new era of inter-colonial communications such requests were now made possible.

\footnotetext{
${ }^{39}$ Kathy De La Rue, The Evolution of Darwin, 1869-1911, A History of the Northern Territory's capital city during the years of South Australian administration (Darwin: Charles Darwin University Press, 2004), 31.

${ }^{40}$ James Nicol, 'Notebook: Cable Voyages 1870-1874', in History of the Atlantic Cable and Undersea Communications, ed. M. Vickers (1871) Available at http://atlantic-cable.com/CableStories/Nicol/ (accessed 11 December 2013).

${ }^{41}$ Nicol, 'Notebook'.

${ }^{42}$ Ernestine Hill, The Territory, A Sprawling saga of Australia's tropic north (Sydney: Angus \& Robertson Publishers, 1951), 113.

${ }^{43}$ Nicol, 'Notebook'.
} 
The social influence of the telegraph officers in Darwin, and later Broome is most often been remembered for their determined pursuit of leisure and the playing of manly sports. ${ }^{44}$ Such leisure activities were a preoccupation for colonials in the Indian Ocean colonies, where, as Mrinalini Sinha explains, keeping active was imagined as an English virtue that set colonials apart from the supposedly 'indolent Orientals' ${ }^{45} \mathrm{In}$ their first year in Darwin, while the Cable residence was under construction, Douglas offered to provide a home for the BAT billiard table in his new Government residence where telegraph officers could spend 'pleasant evenings'. ${ }^{46}$ The close relationship between company and administration was sealed when Darwin manager, J.E. Squier (later Australian manager) married Douglas' daughter Eleanor. ${ }^{47}$

After doubts were expressed over Douglas' administration, he chose to resign in 1873. Arriving by steamer from Adelaide, the new Government Resident, George Byng Scott came with more officials and a newspaper plant and staff to start the Northern Territory Times and Gazette. The newspaper began by announcing Darwin as an Indian Ocean colony, stating:

It is to the present population of twelve or fourteen hundred people that the credit will belong of founding the first British colony on the Australian shores of the Indian Ocean... ${ }^{48}$

\footnotetext{
${ }^{44}$ Matthew Stephen, Contact Zones: Sport and Race in the Northern Territory 1869-1953 (Darwin: Charles Darwin University Press, 2010), 50.

${ }^{45}$ Mrinalini Sinha, Colonial Masculinity: The 'Manly Englishman' and the 'Effeminate Bengali' in the Late Nineteenth Century (Manchester: Manchester University Press, 1995).

${ }^{46}$ South Australia Register, 3 June 1872, 6.

${ }^{47}$ South Australian Chronicle and Weekly Mail, 27 July 1872, 7; South Australian Register, 21 July 1873,5

${ }^{48}$ Northern Territory Times and Gazette, 14 November 1873, 2.
} 
There is no doubt that this new Indian Ocean colony was regarded as the product of the telegraph line. Even so, a less enthusiastic commentator acknowledged that despite the telegraph allowing them to communicate with the world, Port Darwin 'was almost as much isolated as though it were one of the islands of the Indian archipelago' ${ }^{49}$ The voyage to Darwin from Adelaide took twenty-nine days and there was as yet no regular shipping schedule and little opportunity to travel to population centres in eastern and southern Australia..$^{50}$

\section{Asian labour for north Australia}

Colonial racialised understandings of the late nineteenth century deemed that white men were not capable of labouring in the tropical heat and would have to rely on Asian workers for housework and other manual labour. But this climatic view of the world came under challenge as Australian nationalists sought to claim the continent as the domain of 'white men' and 'white workers'. According to Marilyn Lake and Henry Reynolds, the notion that 'inherently servile' Asian labour 'degraded the status of all labour' was a core belief of liberal theorists in Australia and England. Indeed in Australia both Liberal and Labor parties agreed on the exclusionary principal of White Australia in order to protect 'white' wages and conditions. ${ }^{51}$ Nevertheless,

\footnotetext{
${ }^{49}$ Northern Territory Times and Gazette, 26 December 1873, 2.

${ }^{50}$ Kapunda Herald and Northern Intelligencer, 9 September 1873, 2.

${ }^{51}$ Marilyn Lake and Henry Reynolds, Drawing the Global Colour Line: White Men's Countries and the Question of Racial Equality (Melbourne: Melbourne University Press, 2008), 153.
} 
despite the vocal opposition to Asian labour, there remained many influential supporters. $^{52}$

While Labor leaders since the 1880s had stigmatised Chinese workers as cheap 'coolie' labour, the South Australian government allowed C. and E. Millar to import some 150 Indian and Singalese labourers from Singapore along with some 3,000 Chinese workers to complete the Darwin to Pine Creek railway. ${ }^{53}$ Chinese wages were regarded as cheap at $£ 5$ to $£ 6$ per month. Europeans were employed as gangers but not for heavy labour on account of the heat. ${ }^{54}$ Lord Brassey, British Liberal parliamentarian and later governor of Victoria, addressed the Adelaide Chamber of Commerce in 1887, speaking in favour of Asian labour in the north, 'where the Anglo Saxon race cannot perform manual labor', arguing that the more temperate south should be reserved 'for our own race' ${ }^{55}$ Alfred Searcy, Sub-Collector of Custom in Darwin from 1882 to 1896, proposed in 1907 shifting the colour line

\footnotetext{
${ }^{52}$ Warwick Anderson, The Cultivation of Whiteness, Science, Health and Racial Destiny in Australia, (Melbourne: Melbourne University Publishing, 2005), 73; Russell McGregor, 'A Dog in the Manger:
} White Australia and its Vast Empty Spaces’, Australian Historical Studies 43, no. 2 (2012): 157-73.

${ }^{53}$ John Fitzgerald, Big White Lie, Chinese Australians in White Australia (Sydney: University of New South Wales Press, 2007), 62-5; Marilyn Lake, 'Challenging the 'Slave-Driving Employers':

Understanding Victoria’s 1896 Minimum Wage through a World History Approach', Australian Historical Studies 45, no. 1 (2014): 93-4; South Australian Government, 'Government Resident's Report on Northern Territory for the Year 1888', www.aiatsis.gov.au (accessed 12 June 2013), 13. 54 ‘The Northern Territory and its Prospects', Evening Journal, 19 January 1888, 3.

${ }^{55}$ Annie Brassey, The Last Voyage to India and Australia in the 'Sunbeam', November 1886-December 1887 (London: Longmans, Green \& Co., 1889), 468; B. R. Penny, 'Brassey, Thomas (1836-1918)', Australian Dictionary of Biography, National Centre of Biography, Australian National University, http://adb.anu.edu.au/biography/brassey-thomas-5339/text8947, published first in hardcopy 1979, (accessed 16 November 2015). 
southwards from Darwin to coincide with the tropic of Capricorn, to allow the north to be developed according to tropical colonial conditions elsewhere. ${ }^{56}$

One of the first domestic servants to arrive in Darwin, before the establishment of the telegraph, was a young man called Omah, who sailed from Kupang in Dutch Timor in 1871 to work for Douglas. Douglas' daughter Harriet recalled his arrival: 'I then heard spoken for the first time what now is as familiar to me as my mother tongue, the melodious Malayan'. She describes the relationship between her family and Omah, writing: 'My father had not spoken Malay for twenty years, but it came back to him after a few days' practice. We soon learnt the language, and held long conversations with Omah in his native dialect' ${ }^{57}$ This rare glimpse of the private master-servant relationship suggests a more respectful attitude towards Omah compared to the usual stereotype of servants as silent and submissive.

In 1873 Thomas Reynolds, Crown Commissioner of Lands for South Australia visited Singapore, Batavia, Semarang, Surabaya, Makassar, and Dutch Timor in search of suitable labour for Darwin. ${ }^{58}$ Reynolds was assured of the availability of labour in those eastern islands but eventually recommended a mixture of workers, preferring Malays and Singalese as house servants. ${ }^{59}$ In early nineteenth-century New South Wales there had been a preference for Indian servants, particularly from officials who had served in India, but British restrictions on Indian immigration to

\footnotetext{
${ }^{56}$ Alfred Searcy, In Australian Tropics (London: George Robertson \& Co., 1909), 363.

${ }^{57}$ Mrs Dominic (Harriet) D. Daly, Digging, Squatting and Pioneering Life in the Northern Territory of South Australia (London: Sampson Low, Marston, Searle and Rivington, 1887), 127-28.

${ }^{58}$ South Australian Register, 15 July 1873, 3; Sydney Morning Herald, 20 May 1873, 5; Bataviaasch Handelsblad, 26 June 1873, 3.

${ }^{59}$ South Australian Register, 26 July 1872, 6; Argus, 30 November 1872, 5; Sydney Morning Herald, 20 May 1873, 5; South Australian Register, 24 August 1874, 5.
} 
Australia prevented large-scale immigration. ${ }^{60}$ In the 1870 s the South Australian parliament also favoured Indian immigration for the Northern Territory on the grounds that they were British subjects and were, in the racial stereotyping of the period, imagined to be 'quiet, docile, steady and industrious ${ }^{61}$ Singapore already had a large population of Indian labourers and was positioned as a hub for labour recruitment to the region. But Singapore was constrained, with the Viceroy of India issuing instructions in 1874 and again in 1876 insisting that the Straits Settlements curtail Indian immigration. ${ }^{62}$ After Douglas resigned his post he was sent to Singapore planning to engage 200-300 Chinese or Indian workers. He returned with only 187 Chinese workers on two year contracts to work as general servants for eight shillings a week (less than $£ 2$ per month) plus food and medical attention. Most became miners with only four listed as working in private homes. ${ }^{63}$

While there is no surviving record of Indian immigration to Darwin in this early period, writer Ernestine Hill claimed that telegraph officers in Darwin employed

\footnotetext{
${ }^{60}$ James Broadbent, Suzanne Rickard, and Margaret Steven, India, China and Australia: Trade and Society 1788-1850 (Sydney: Historic Houses Trust of New South Wales 2003), 84; Ann Curthoys, 'Liberalism and Exclusionism: A Prehistory of the White Australia Policy', in Legacies of White Australia: Race, Culture and Nation, eds. Laksiri Jayasuriya, David Walker and Jan Gothard (Perth: University of Western Australia Press, 2003), 11-12; David Northrup, Indentured Labor in the Age of Imperialism 1834-1922 (Cambridge: CUP Archive, 1995), 63.

${ }^{61}$ South Australian Register, 24 June 1875, 4.

${ }^{62}$ Queenslander, 11 March 1876, 20; 'Straits Emigration Bill', Straits Times, 28 October 1876, 1.

${ }^{63}$ Northern Territory Times and Gazette, 29 May 1874, 3; Paul A. Rosenzweig, The House of Seven Gables, A History of Government House Darwin (Darwin: Historical Society of the Northern Territory, 1996); Timothy G. Jones, The Chinese in the Northern Territory (Darwin: Charles Darwin University Press 2005), 5-9.
} 
both Indian and Aboriginal servants. These 'sahibs', she wrote, had built themselves a luxury bungalow, a 'Folly' with:

twenty-two rooms, offices, ballroom, billiard-room, a well, a garden, shower-baths, a carriagehouse, stables and a tennis court. Larrakia piccaninnies pulled punkahs over an impressive senior staff with Hindu servants and a sportive crowd of junior johnnies, Englishmen all, from service in the languorous East. ${ }^{64}$

The bungalow, which became distinctive in northern Australian architecture, is now acknowledged to derive from British Indian roots. ${ }^{65}$

Indian servants were also employed in the two neighbouring telegraph stations of Banyuwangi and Broome. In the 1880s, before the Broome station was opened, an Australian visitor to the telegraph station at Banyuwangi, Reverend J.E. Tenison Woods, published his impressions. Arriving on the British India Steam Navigation Company's S. S. Chyebassa, he disembarked and described the Indian crew of the pilot boat, noting their meticulously white and brightly-coloured uniforms. Their guides took them to the telegraph office where they found an Englishman at work in extreme heat. He was excited to witness a message arriving from Australia and commented, 'Those who enjoy the fruits of our Port Darwin cable little know the toils of the telegraph operator at Banjoewangie'. ${ }^{66}$ That evening they were put up at a private residence in the English kampong and Tenison Woods took pleasure in his surrounds, admiring the furnished verandah the size of a house, and its huge, airy and

\footnotetext{
${ }^{64}$ Hill, 125; On Aboriginal servants see Julia Martínez and Claire Lowrie, 'Colonial Constructions of Masculinity: Transforming Aboriginal Australian Men into 'Houseboys', Gender and History 21, no. 2 (2009): 308

${ }^{65}$ D. C. Bridgman, 'The Anglo-Asian Bungalow: Housing the Commonwealth Officer in the northern tropics of Australia', (PhD thesis, RMIT, 2006), 26

${ }^{66}$ Sydney Morning Herald, 27 February 1884, 5.
} 
clean bedrooms. Even after living in Australia for thirty years, British-born Tenison Woods was at home in this British colonial lifestyle. He was on his way to Singapore to visit Sir Frederick Weld, Governor of the Straits Settlements (1879-87), another advocate of Australian-Indian Ocean connections having previously been Governor of Western Australia (1868-74) and responsible for the pearling industry. ${ }^{67}$

Visiting NSW parliamentarian, Yorkshire-born Henry Copeland offered an alternative perspective on the Banyuwangi station. Though conscious of the importance of the telegraph station, he did not approve of the culture milieu. Even though he himself employed Asian servants during his trip, he believed that the 'penchant for servants' was a sign of British moral decay brought on by the tropical heat. ${ }^{68}$ The Australian ideal, as Warwick Anderson discusses, advocated the development of a new white man, adapted to work in the tropics, while preserving racial purity. ${ }^{69}$ The suggestion of 'moral decay' referred to all those aspects that the new nation of Australia would reject: the exploitation of slave-like labour; intimate mixing with non-white races; and the elitism implied by the ostentatious display of servants. $^{70}$

Asian workers were subsequently employed in the cable station in Broome. The town had been established in 1883 as a base for the pearling industry, but also in

\footnotetext{
${ }^{67}$ T.S. Louch, 'Weld, Sir Frederick Aloysius (1823-1891)', Australian Dictionary of Biography, http://adb.anu.edu.au/biography/weld-sir-frederick-aloysius-4829, (accessed 12 November, 2014).

${ }^{68}$ Battersby, 82 .

${ }^{69}$ Warwick Anderson, 'Ambiguities of Race: Science on the Reproductive Frontier of Australia and the Pacific Between the Wars', Australian Historical Studies 40. no. 2 (2009): 143.

${ }^{70}$ For Dutch East Indies' culture of domestic service see Ann Laura Stoler, Carnal Knowledge and Imperial Power: Race and the Intimate in Colonial Rule (Berkeley: University of California Press 2002).
} 
time for the arrival of the telegraph in 1889. The cable station was built by Cantonese labour on indentured contracts from Singapore, included a foreman, eleven carpenters, five masons, and a general labourer. H. W. MacPherson, superintendent for the Eastern Extension, also imported a Hailam cook and four Hailam 'boys'. Their wages were $\$ 25(£ 5)$ per month, slightly higher than the $\$ 20(£ 4)$ paid to the other labourers and compatible with the railway workers' wages. ${ }^{71}$ Four months later the SS. Australind arrived in Western Australia with forty-one Chinese workers, including 17 Hokkien, 13 Hailam, 7 Cantonese, 3 Hui Chin, and one Kheh cook. They arrived on two and three-year contracts and their wages varied from $\$ 18$ per month for one Hailam cook to $\$ 8$ for the Kheh cook, who was presumably cook for the other labourers. $^{72}$

In addition to Chinese, there were also Indian domestic workers in the Broome cable station. ${ }^{73}$ These servants were publicly described as being handsomely dressed in white uniforms with red sashes and turbans. ${ }^{74}$ One commentator in the newspaper remarked in 1898:

\footnotetext{
${ }^{71}$ Passengers on S.S. Suno, 9 February 1889, Cons. 527, 1889/0762, State Records Office of Western Australia (hereafter SROWA), Perth.

${ }^{72}$ Passengers on S.S. Australind, 1 July 1889, Cons. 527, 1889/2090, SROWA.

${ }^{73}$ This Western Australian government permission was in a separate agreement to the original agreement signed with the South Australian government for Darwin. Extract from letter describing Broome's early telegraph link, DOC/EEACTC/1889-1914; DOC/BATC/1/3 1871 August 29 Agreement between Governor of South Australia and the British Australian Telegraph Company for landing of cable at Port Darwin, Eastern Extension Telegraph Companies Files, Cable and Wireless Archive, Porthcurno, UK.

${ }^{74}$ Susan Sickert, Beyond the Lattice, Broome's Early Years (Fremantle: Fremantle Arts Press 2003), 36.
} 
To a visitor landing at Broome the town and people would give him the impression that he had landed at an eastern Town rather than at an Australian one. ... On shore all domestic work is done with coloured servants, they being engaged as cooks, house boys, washermen, etc. ${ }^{75}$

\section{Asian domestic servants during White Australia}

With the passing of the Immigration Restriction Act of 1901, Asian labour migration was virtually banned as part of the White Australia policy. An exemption was granted to the pearling industry which continued to employ indentured Asian labour. In 1903 as the question of Asian workers for Broome was debated in parliament, anti-Labor journalist William J. Sowden argued that the Federal government was trying to impose a 'White Indian Ocean policy', describing this interference as 'utter folly'. The Federal investigation into the recruitment conditions for the pearling industry found that in 1903 Malay indentured workers from Singapore were on three-year contracts with wages of $£ 2.10 .0$ per month, plus basic food, accommodation and medical care. The government allowed the continued importation of Asian labour in pearling, only because the pearling masters threatened to move the industry off-shore to the Dutch East Indies. ${ }^{77}$

Labor Senator Hugh De Largie spoke in the Senate in 1908 on the need for immigration restriction. He claimed that in Broome there were men who having:

lived in India for a considerable number of years, and imbibed the opinions of men living in

Oriental countries, ... seem to entertain a supreme contempt for any white man who has to earn his living by means of heavy or laborious work. They think that the white man should be "boss"

\footnotetext{
${ }^{75}$ Western Mail, 14 January 1898, 45.

76 'With the Nor 'West Mail', Register, 20 April 1903, 5.

${ }^{77}$ Martínez and Vickers, 79-80.
} 
of the coloured man, and consequently they look upon Asiatic immigration quite differently from the average Australian. ${ }^{78}$

The telegraph officers were not typical Australians by any stretch of the imagination, but this did not diminish their influence within elite Darwin and Broome society. This influence was the subject of irreverent anecdotes such as one newspaper article 'Socialites at Broome' expressing dismay to find that people in:

Broome wear dark, hot and heavy garments at public functions because it's English you know. The inhabitants have long followed the example of the cable-house, which wouldn't get out of the conservative sartorial rut of the old country for the world. ${ }^{79}$

Tracing the lives of Asian immigrant workers to Australia is made possible by the record keeping prompted by the Immigration Restriction Act of 1901, which provides us with personal details: a name, a photograph, a place of origin, as well as documenting their movements in and out of Australia. They offer us glimpses of 'subaltern lives' and their mobilities in much the way Clare Anderson has employed Asian convict records. ${ }^{80}$ But without written sources penned by the workers themselves, for other details we rely on the writings of their employers. In 1903, for example, the Broome Tennis Club held a ball which was glowingly described in the newspapers, including the fact that: 'the excellent servants of the Cable Co.'s mess did the waiting and it would be hard to improve on the manner in which they performed their duties' ${ }^{81}$

\footnotetext{
${ }^{78}$ Senator Hugh De Largie, Senate Hansard, 11 December 1908.

79 'Socialites at Broome', Sunday Times (Perth), 7 August 1910, 15.

${ }^{80}$ Clare Anderson, Subaltern Lives, Biographies of Colonialism in the Indian Ocean World, 1790-1920

(Cambridge: Cambridge University Press 2012), 2.

${ }^{81}$ Western Mail, 18 July 1903, 42.
} 
This colonial idyll was interrupted in 1904, when, under Labor Prime Minister Chris Watson, Broome's Asian servants were deported. The preference for white labour was a key platform of the Labor Party. As Margaret Allen describes, a number of Indian immigrants were deported, being unable to negotiate past the new immigration restrictions. These included one Indian man in business in Perth, and a domestic servant in NSW who, though domiciled, was refused permission to bring his intended wife to Australia. ${ }^{82}$

When conservative Prime Minister George Reid took over government in 1905 there was a softening of the Immigration Restriction Act to allow non-white students, tourists and bone fide merchants to enter on temporary exemptions. ${ }^{83}$ The Eastern Extension asked for the return of their domestic workers, even though they were not of the exempted class. In January 1905, approval was given to re-employ three servants. One was Marjoeki (also Matjugi), a Javanese man, who was allowed to enter Australia freely, on the grounds that he had been resident in Australia before $1901 .^{84}$ The two others, A. Vembly and R. Arokiasamy, from India, were granted a temporary Certificate of Exemption to remain in Australia for two years. ${ }^{85}$

The Eastern Extension officers were not alone in their desire to employ Asian servants. In 1906, a public meeting, called by the mayor of Broome, passed a

\footnotetext{
${ }^{82}$ Margaret Allen, “'Innocents Abroad' and 'Prohibited Immigrants': Australians in India and Indians in Australia, 1890-1910', in Connected Worlds: History in Transnational Perspective, eds. Ann Curthoys and Marilyn Lake (Canberra: ANU E-Press 2005), 121-23. See also Marie de Lepervanche, Indians in a White Australia, An Account of Race, Class, and Indian Immigration to Eastern Australia (Sydney: Allen \& Unwin 1984).

${ }^{83}$ Allen, 121.

84 ‘Marjoeki, Indonesian’, K1145/1, 1923/18, Barcode 1742272, NAA, Perth.

85 'Eastern Extension', Barcode 16092, NAA, ** Perth or elsewhere? **.
} 
resolution protesting against the Immigration Restriction Act and demanding that each household be allowed to import three 'Asiatic' domestic servants on three-year fixed contracts. They decided to telegraph these resolutions to all towns north of the Tropic of Capricorn, asking for their cooperation. ${ }^{86}$ Thus when Warren, as manager for the Eastern Extension requested two new servants for Broome it was in the context of this broader lobby. Warren received permission from the Department of External Affairs and then contacted their manager in Singapore to make the travel arrangements. ${ }^{87}$

On 14 December 1907 two new workers arrived to replace those whose term of engagement expired on April 1908. Mylappen Rathnam and Corneley Jacob Joseph arrived respectively on 16 March 1908 and on 17 February 1910 and were granted permission to remain for another year. ${ }^{88}$ These arrangements were made during the term of Prime Minister Alfred Deakin who was known to advocate the idea of tropical Australia being located 'within an Indian sphere of influence', including the suggestion that a case could be made for the importation of Hindu workers into northern Australia. ${ }^{89}$

With the election of Labor Prime Minister Andrew Fisher in 1910 the push for a white labour policy was strengthened. ${ }^{90}$ In June 1910 , Fenton in Broome wrote to justify their continued employment of Indian labour, to the Sub-Collector of Customs, claiming that their servants would not offer competition to white workers, being 'not

\footnotetext{
${ }^{86}$ Western Mail, 17 February 1906, 49.

${ }^{87}$ Warren, 17 December 1907, ‘Eastern Extension’, Barcode 16092, NAA.

88 'Eastern Extension', Barcode 16092, NAA.

${ }^{89}$ David Walker, 'India, The Antique Orient', in Wanderings in India, Australian Perceptions, eds. Rick Hosking and Amit Sarwal (Melbourne: Monash University Publishing, 2012), 11-13.

${ }^{90}$ Julia Martínez, 'Questioning 'White Australia': Unionism and 'Coloured' Labour, 1911-37', Labour History, 76 (May 1999): 2.
} 
be required to do any work extraneous to our strict requirements'. On 27 July 1910 Atlee Hunt, Secretary of External Affairs, responded denying their request for new servants. ${ }^{91}$

Broome rallied behind Cable House; the mayor called a public meeting, requesting the full attendance 'of the ladies of Broome', to petition the government for permission 'to indent Asiatic servants for domestic purposes' ${ }^{92}$ Fenton wrote to pearling master Arthur Male, Liberal member for Kimberley, explaining that he had unsuccessfully tried 'to procure servants from Perth, Fremantle and Port Darwin', adding: 'This proves the desire of my Company to respect the laws of the land'. Stressing that the Broome cable station was running at a loss he suggested that the government give them permission to close the station. ${ }^{93}$ The Premier of Western Australia, Frank Wilson, sent an urgent telegraph to the Prime Minister, asking him to honour the agreement made between the states and the Eastern Extension Company. He added that the servants they had requested were southern Indians and British subjects. This British imperial notion, whereby subjects of empire should not be excluded on the basis of 'race' was out of step with the 'race'-based White Australia policy. ${ }^{94}$ The Federal government made inquiries as to the terms of the agreement with the Company, to ascertain their legal obligations. Satisfied that there was no special case to be made, on 22 February 1911, Prime Minister Andrew Fisher

\footnotetext{
91 'Eastern Extension’, Barcode 16092, NAA.

${ }^{92}$ Northern Times, 27 August 1910, 2.

${ }^{93}$ J.C. Fenton to A. Male, 18 December 1910, 'Eastern Extension Cable Co. Broome - re employment of native servants', Cons 1496, 1912/0038, SROWA.

${ }^{94}$ Lake and Reynolds, 5.
} 
responded to Wilson that the exemption would not be granted. Rathnam and Joseph left Australia together in March $1911 .^{95}$

At least two of the servants employed in 1910 had chosen to leave the Cable House employ of their own accord. Fenton wrote that Marjoeki had 'refused to return to service on our terms' while the other was a 'locally engaged man ... who wishes to resume the avocation of a Pearl-Shell diver'. ${ }^{96}$ Even the pearling industry was not secure in its ability to employ Asian workers; in 1912 the government issued a ban on Asian pearling workers to take effect in $1913 .^{97}$

Marjoeki left for Singapore without receiving his Certificate of Exemption from the Dictation Test (CEDT), but the Acting Collector of Customs wrote to Atlee Hunt assuring him that Marjoeki's departure was with his approval, as he was 'a well known resident of Broome'. ${ }^{98}$ Marjoeki was able to return to Broome, applying for permission to leave Australia again in 1914 and in 1922.

In the photograph below, Josiah Fenton, appears with his wife and daughter and five Asian servants. Marjoeki is standing third from the left. Anglican Bishop Trower was Fenton's guest, having arrived in 1910 from Nyasaland (Malawi) Africa. Both men continued to lobby to import Asian domestic servants until the mid-1920s. ${ }^{99}$ This photograph might appear to be a celebration of the imperial culture of the Cable House with its full complement of Asian servants, but in the context of their failure to persuade the Australian government to continue the exemption, it was perhaps

\footnotetext{
${ }^{95}$ Note on External Affairs memo, 'Eastern Extension', Barcode 16092, NAA.

${ }^{96}$ J.C. Fenton to Sub Collector of Customs, Broome, 25 June 1910, Barcode 16092, NAA.

${ }^{97}$ Martínez and Vickers, 80.

${ }^{98}$ Acting Collector of Customs, to Secretary, External Affairs, 19 July 1910, Barcode 16092, NAA.

99 'Obituary, Bishop Trower', Northern Times, 1 September 1928, 3; 'Coloured labour, Senator Pearce's Opinion', West Australian, 24 June 1924, 7.
} 
intended as a record of the end of an era. In March 1914, citing their inability to secure appropriate servants, Eastern Extension shut down the Broome Cable Station. INSERT FIGURE 1 HERE

In 1913, L. Webster, the Australasian Manager, wrote to the Premier of Western Australia advising him that while their Agreement of 1900 stipulated that they required the Premier's written consent to shut down the station, this 'undertaking was given at a time when the Company was enjoying the privilege of importing native Indian servants and the existing trouble was entirely unforeseen' ${ }^{100}$ The telegraph station in Broome was no longer of sufficient strategic importance to warrant special exemptions. The alternative cable from Cocos Island to Perth was in place, while wireless radio stations established in Darwin and Broome signalled a new era in telecommunications.

Two years later, the newly appointed Liberal Minister for External Affairs, Paddy Glynn, wrote to Atlee Hunt asking about the decision to deny the company exemptions for their Asian servants in the context of the closure of the Broome station. Hunt defended the decision, arguing that if they had agreed to their request for 'coloured' servants they would have had to agree to other requests from private individuals. Hunt concluded that the closing of the station 'is hardly our affair'. ${ }^{101}$

Marjoeki had left Australia in 1914 but returned to Broome in 1916 and according to his Alien Registration-a requirement of the War Precautions

\footnotetext{
100 'Eastern Extension Cable Co. Broome', SROWA.

101 'Eastern Extension', Barcode 16092, NAA.
} 
Regulations - he was working for Bishop Trower as a 'handy man' ${ }^{102}$ The year 1916 saw a victory for the Asian labour lobby, with the long-running Royal Commission into the pearling industry finding in favour of continued Asian indentured labour on the grounds that the industry was too dangerous for white men. ${ }^{103}$ The decision spurred the domestic labour lobby to continue, but they did not have the financial clout of the pearling industry. Subsequent requests to import Asian domestic workers in 1918 and 1919 by Broome residents were all denied. ${ }^{104}$

\section{Conclusion}

The laying of the Indian Ocean telegraph was a catalyst that not only encouraged the colonisation of north Australia but also the transfer of Indian Ocean colonial culture. With the cable came the telegraph officers who aimed to create north Australia in the image of the Indian Ocean colonies. Their insistence that Asian domestic servants should be permitted to immigrate to north Australia was part of that project. Even as Australian nationalists attempted to restrict Asian labour, the political influence of the telegraph company was such that they were able to obtain exemptions from the White Australia policy, though these were notably granted during periods of Liberal government.

The Eastern Extension officers who travelled along the telegraph line sought to assert their status as imperial masters through their employment of Asian servants. But by 1911, after forty years in north Australia, the company was nearing the end of its monopoly on the provision of global communications and it would struggle to

\footnotetext{
${ }^{102}$ Form of Application for Registration, 1916, Javanese/Marjoeki, PP14/3, Barcode 4282500, NAA.

${ }^{103}$ Martínez and Vickers, 80.

104 'Admission of Male Asiatic Servants at Broome', A1 1920/6227, Barcode 38590, NAA.
} 
maintain its influence over the Australian government. Nevertheless, those crucial early decades left their stamp on the multi-ethnic character of north Australian society.

This exploration of the establishment of the Indian-Australian telegraph cable seeks to anchor the historiography of north Australia to that of Indian Ocean imperial history. Even as the technology of the cable served to bind Australia more closely to Britain, thus apparently reinforcing the ambitions of the white settler society, its employees in northern Australia sought to limit the continental spread of White Australia. The demands made by Eastern Extension suggest an assumption of imperial prerogative, which they understood to outweigh the nationalist agenda of immigration restriction. They reflected the tension between government policy and commercial considerations, a tension which was echoed in other north Australian businesses.

\section{Julia Martínez}

University of Wollongong

Email: juliam@uow.edu.au 